\title{
INTERACTION OF SALINITY AND BORON IN WHEAT AFFECTS PHYSIOLOGICAL ATTRIBUTES, GROWTH AND ACTIVITY OF ANTIOXIDANT ENZYMES
}

\author{
Tayyaba Naz ${ }^{1,2, *}$, Javaid Akhtar ${ }^{1,2}$, Muhammad Anwar-ul-Haq ${ }^{1,2}$, Muhammad Saqib ${ }^{1,2}$, \\ Muhammad Mazhar Iqbal ${ }^{1,3}$ and Muhammad Shahid ${ }^{4}$
}

\author{
${ }^{1}$ Institute of Soil and Environmental Sciences, University of Agriculture Faisalabad, Pakistan; ${ }^{2}$ Saline Agriculture \\ Research Centre, University of Agriculture Faisalabad, Pakistan; ${ }^{3}$ Soil and Water Testing Laboratory, Chiniot, \\ Department of Agriculture, Government of Punjab, Pakistan; ${ }^{4}$ Department of Biochemistry, \\ Faculty of Sciences, University of Agriculture Faisalabad, Pakistan. \\ *Corresponding author's e-mail: tayyaba.uaf@gmail.com
}

\begin{abstract}
Boron (B) is an essential nutrient required in very small amount by crop plants and it can become toxic to plants when present in slightly higher amount. Increasing concentration of B is often found in association with salinity. The presence of salinity and high B may result in synergistic or antagonistic effects on plant growth. A hydroponic trial was conducted to evaluate the influence of various levels of B on the growth, physiological and biochemical responses of salt tolerant and sensitive wheat genotypes under saline conditions. The present study comprised of twelve treatments including four rates of B (control, 0.5, 1 and $1.5 \mathrm{mM}$ ) and three levels of salinity (control, 100 and $200 \mathrm{mM} \mathrm{NaCl}$ ). Two salt tolerant (SARC-I and Sehar-2006) and two salt sensitive (Koistan-90 and MH-97) wheat genotypes were used. The tested salt tolerant and sensitive wheat genotypes showed significant variations and responded differently to salinity and B individually as well as in combination. The salt tolerant genotypes showed better growth due to high antioxidant activity, maintenance of photosynthesis and stomatal conductance and low leaf $\mathrm{Na}, \mathrm{B}$ and $\mathrm{Cl}$ concentration in the presence of individual and combined stresses of salinity and high B as compared to sensitive genotypes. The highest level of salinity and B in combination caused the highest reduction in plant growth as compared to their respective controls. However the interactive effect of salinity and boron was antagonistic as increasing salinity reduced boron toxicity while increasing boron reduced harmful effects of salinity on growth and physiological attributes of wheat.
\end{abstract}

Keywords: Wheat, salinity, B toxicity, physiological functions, enzymes

\section{INTRODUCTION}

Salinity is a serious problem affecting plant growth and crop yields around the globe (Esfandiari et al., 2007). Salinity affects plant growth by increasing osmotic potential of soil solution and thus decreasing water availability to plants; specific effects of some ions such as $\mathrm{Na}^{+}, \mathrm{Cl}^{-}$when present in high concentrations and oxidative stress (Yamaguchi and Blumwald, 2005). Salinity also affects physiological processes in plants such as photosynthesis by decreasing stomatal conductance (SC) and transpiration and distressing the synthesis of photosynthetic pigments (Sairam et al., 2005; Faried et al., 2016; Parveen et al., 2016).

Boron is essential plant nutrient required for normal growth of plants. Boron is frequently associated with other salts and its high concentration is commonly found in irrigation water and soils of arid regions (Nable et al., 1997). The toxicity of $\mathrm{B}$ is an important disorder that negatively affects physiological processes in plants such as decreased root and shoot growth (Masood et al., 2012), inhibited photosynthesis (Guidi et al., 2011), reduced SC (Sheng et al., 2009), lipids peroxidation and modified activities of antioxidant enzymes (Keles et al., 2004). The photosynthetic transport of electrons is disrupted owing to salinity and B toxicity leading to the production of reactive oxygen species (ROS) (Molassiotis et al., 2006). Hot water soluble B concentration of $5 \mathrm{mg} \mathrm{kg}^{-1}$ or more in soil is considered toxic for plants (Nable et al., 1997). The crop plants encounter simultaneous stresses of salinity and B toxicity when they are either irrigated with high B and salts containing water or grown in soils with naturally occurring salinity and high B. Both of these conditions usually occur in semi-arid and arid regions having low rainfall and poor drainage (Nable et al., 1997). Irrigation with high B containing saline groundwater is practiced worldwide (Wimmer et al., 2003).

Salinity and B toxicity in combination, affect photosynthesis in plants by disrupting the photosynthetic pigment's biosynthesis and also affect membrane functions (Karabal et al., 2003). Salinity and B toxicity limits growth and yield of many crops including wheat (Grieve and Poss, 2000). Boron tolerance mechanism is not clearly understood and documented particularly under saline conditions. 
The generation of ROS such as superoxide, hydroxyl radicals and hydrogen peroxide is one of the important biochemical changes that take place in plants subjected to environmental stresses (Grieve and Poss, 2000). In plants an effective scavenging system consisting of antioxidant enzymes such as superoxide dismutase (SOD) and catalase (CAT) operates to evade the detrimental effects of these ROS (Agarwal and Pandey, 2004). The antioxidative enzyme activities in plants subjected to stress are commonly considered as an indicator of genotype tolerance to stress conditions (Hernandez et al., 2001).

It is expected that crop species/genotypes having better salt tolerance, in general, could absorb and accumulate less B under B-toxic conditions (Nable et al., 1997). Variation in salinity and B accumulation amongst wheat varieties has been previously observed (Wimmer and Goldbach, 2012). Previous research reports described the effect of individual stresses of B toxicity and salinity on plant growth but their interactive effects on growth and yield of crops are still controversial (Yermiyahu et al., 2008; Wimmer and Goldbach, 2012). Variable opinions exist in literature about the interactive effects of both B toxicity and salinity on plants growth. It has been described that severity of B toxicity is reduced by salinity because of reduced accumulation of $B$ in shoot and stem of sorghum (Ismail, 2003). In contrast there was more reduction in the growth of cucumber and tomato by combined B toxicity and salinity than by the individual stresses (Alpaslan and Gunes, 2001). Therefore, a solution culture study was conducted to evaluate the growth, physiological and antioxidative enzymes responses of four wheat genotypes (differing in tolerance to salinity) exposed to exogenously applied salinity, high B and their combined stresses.

\section{MATERIALS AND METHODS}

Experimental layout: A solution culture study was carried out at Institute of Soil and Environmental Sciences, University of Agriculture Faisalabad, Pakistan. Healthy seeds of two salt-tolerant (SARC-I, Sehar-2006) and two saltsensitive (Kohistan-90, MH-97) wheat genotypes were collected from Saline Agriculture Research Centre (SARC) and Ayub Agricultural Research Institute, Faisalabad. The seeds were sown in trays having six inches layer of sand. When wheat seedlings were reached to two leaf stage i.e., after ten days, these were transplanted in thermopore sheets having holes and floating on half strength Hoagland's solution (Hoagland and Arnon, 1950). After six days of transplanting, the following twelve treatments were established as $\mathrm{T}_{1}=$ control, $\mathrm{T}_{2}=0.5 \mathrm{mM} \mathrm{B}, \mathrm{T}_{3}=1 \mathrm{mM} \mathrm{B}, \mathrm{T}_{4}$ $=1.5 \mathrm{mM} \mathrm{B}, \mathrm{T}_{5}=100 \mathrm{mM} \mathrm{NaCl}, \mathrm{T}_{6}=100 \mathrm{mM} \mathrm{NaCl}+0.5$ $\mathrm{mM} \mathrm{B}, \mathrm{T}_{7}=100 \mathrm{mM} \mathrm{NaCl}+1 \mathrm{mM} \mathrm{B}, \mathrm{T}_{8}=100 \mathrm{mM} \mathrm{NaCl}+$ $1.5 \mathrm{mM} \mathrm{B}, \mathrm{T}_{9}=200 \mathrm{mM} \mathrm{NaCl}, \mathrm{T}_{10}=200 \mathrm{mM} \mathrm{NaCl}+0.5$ $\mathrm{mM} \mathrm{B}, \mathrm{T}_{11}=200 \mathrm{mM} \mathrm{NaCl}+1 \mathrm{mM} \mathrm{B}, \mathrm{T}_{12}=200 \mathrm{mM} \mathrm{NaCl}$
$+1.5 \mathrm{mM}$ B. All the chemicals and solvents used were of analytical reagent grade procured from Merck (Darmstadt, Germany). The $\mathrm{H}_{3} \mathrm{BO}_{3}$ was used as a source of $\mathrm{B}$ and the experiment was conducted in completely randomized design with four replications each. The $\mathrm{pH}$ of the treated solutions was maintained between $6 \pm 0.5$ daily. The nutrient solution was changed after every week. The nutrient solution was continuously aerated.

Measurements of growth and physiological parameters and harvesting: Measurements regarding physiological parameters were taken before harvesting on youngest fully expanded wheat leaves. The photosynthetic rate (PR), transpiration rate (TR) and $\mathrm{SC}$ were measured using an open system LCA-4 ADC portable infrared gas analyzer (IRGA, Analytical Development Company, Hoddesdon, England). Plants were harvested after 42 days of applied treatments, and data regarding shoot/root lengths and dry weights were recorded. Samples were then ground for elemental analysis.

Enzyme extraction and assays: For extraction, $0.1 \mathrm{~g}$ fresh leaf samples were taken and ground using a mortar pestle in 5 $\mathrm{ml}$ of $50 \mathrm{mM}$ cooled phosphate buffer $(\mathrm{pH} 7.8)$ placed in an ice bath. After centrifugation of homogenate at $15000 \times \mathrm{g}$ for $20 \mathrm{~min}$ at $4{ }^{\circ} \mathrm{C}$, the supernatant was collected and utilized for the determination of antioxidant enzymes.

The nitro blue tetrazolium (NBT) method was used to determine SOD (Gong et al., 2005). The reaction mixture (3 $\mathrm{mL}$ ) consisting of $13 \mathrm{mM}$ methionine, $50 \mathrm{mM} \mathrm{K}$-phosphate buffer, pH 7.3, 0.1 mM EDTA, $75 \mathrm{mM}$ NBT, enzyme extract $(0.2 \mathrm{~mL})$ and $4 \mathrm{mM}$ riboflavin was prepared. Riboflavin was added last of all, and after shaking, the glass test tubes were placed under fluorescent lamps $\left(60 \mathrm{mmol} \mathrm{m} \mathrm{m}^{-2} \mathrm{~s}^{-1}\right)$. The reaction was allowed for $5 \mathrm{~min}$ and then absorbance was measured at $560 \mathrm{~nm}$. In the same way, controls and blanks were run but without enzyme extract and illumination, respectively.

The CAT was measured as decrease in absorbance at $240 \mathrm{~nm}$ following the decomposition of $\mathrm{H}_{2} \mathrm{O}_{2}$ for 1 min according to the method of Chance and Maehly (1955) as per modifications of Cakmak et al. (1993). The reaction mixture (3 ml) contained $15 \mathrm{mM} \mathrm{H} \mathrm{O}_{2}, 50 \mathrm{mM}$ phosphate buffer $(\mathrm{pH}$ 7.0) and $50 \mu \mathrm{l}$ of crude enzyme extract at $25^{\circ} \mathrm{C}$. The extinction coefficient $\left(40 \mathrm{mM}^{-1} \mathrm{~cm}^{-1}\right)$ for $\mathrm{H}_{2} \mathrm{O}_{2}$ was used for calculating the activity.

Determination of $\mathrm{B}, \mathrm{Na}^{+}, \mathrm{K}^{+}$and $\mathrm{Cl}^{-}$: Dried leaf samples (1 g) were dry-ashed in a muffle furnace at $550^{\circ} \mathrm{C}$ for 6 hours (Chapman and Pratt, 1961). The ash was dissolved in $\mathrm{H}_{2} \mathrm{SO}_{4}$ and then B was determined via spectrophotometer (UVvisible spectrophotometer, RM Marketing, England) at 420 $\mathrm{nm}$ by the azomethine-H method (Bingham, 1982). Sodium and $\mathrm{K}$ were determined by flame photometer (Jenway PFP-7, Loughborough, Leicestershire, UK) following US Salinity Lab. Staff (US Salinity Lab Staff, 1954).

Statistical analysis: Analysis of Variance (ANOVA) was performed on the obtained data and significant differences 
among treatment means (Steel et al., 1997) were calculated by Least Significant Difference (LSD) test at 5\% level of significance using "Statistix 8.1" statistical computer software package(s).

\section{RESULTS AND DISCUSSION}

Plant growth as affected by varying levels of salinity and B: Wheat growth parameters like shoot length, root length, shoot dry weight and root dry weight (Fig. 1a, 1b) decreased significantly $(\mathrm{P} \leq 0.05)$ with salinity, high $\mathrm{B}$ and their interactive effects. Salinity without B had a greater effect on shoot growth than high B. While, root growth was more affected by toxic B alone compared to salinity.
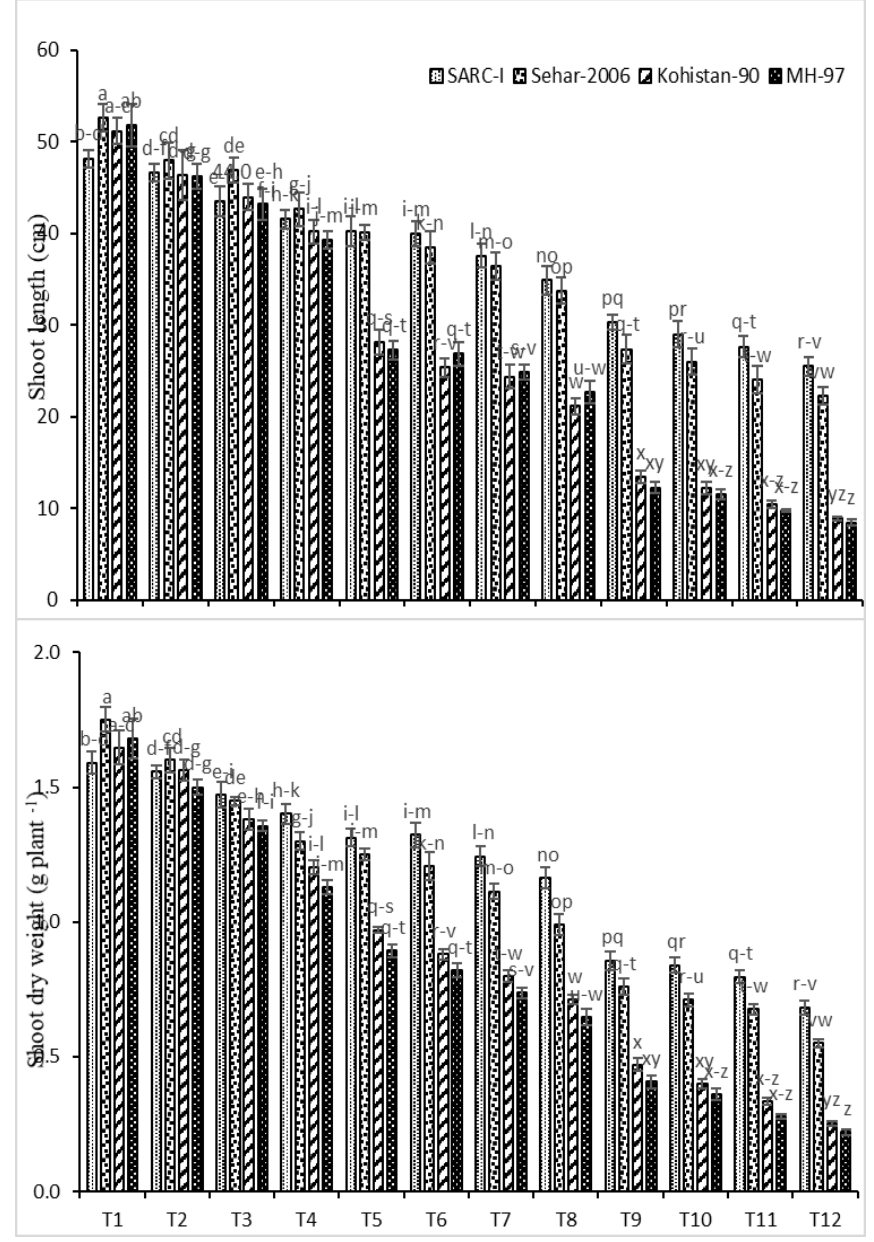

Figure 1a. Effect of varying levels of salinity and $B$ toxicity on growth responses of shoot (Means $\pm S E, n=4)$. $\mathrm{T}_{1}=$ Control, $\mathrm{T}_{2}=0.5 \mathrm{mM} \mathrm{B}, \mathrm{T}_{3}=1 \mathrm{mM} \mathrm{B}, \mathrm{T}_{4}=1.5 \mathrm{mM}$ $\mathrm{B}, \mathrm{T}_{5}=100 \mathrm{mMNaCl}, \mathrm{T}_{6}=100 \mathrm{mMNaCl}+0.5 \mathrm{mM} \mathrm{B}$, $\mathrm{T}_{7}=100 \mathrm{mMNaCl}+1 \mathrm{mM} \mathrm{B}, \mathrm{T}_{8}=100 \mathrm{mMNaCl}+1.5$ $\mathrm{mM} \mathrm{B}, \mathrm{T}_{9}=200 \mathrm{mMNaCl}, \mathrm{T}_{10}=200 \mathrm{mMNaCl}+0.5 \mathrm{mM}$ B, $\mathrm{T}_{11}=200 \mathrm{mMNaCl}+1 \mathrm{mM} \mathrm{B}, \mathrm{T}_{12}=200 \mathrm{mMNaCl}+$ $1.5 \mathrm{mM}$ B.
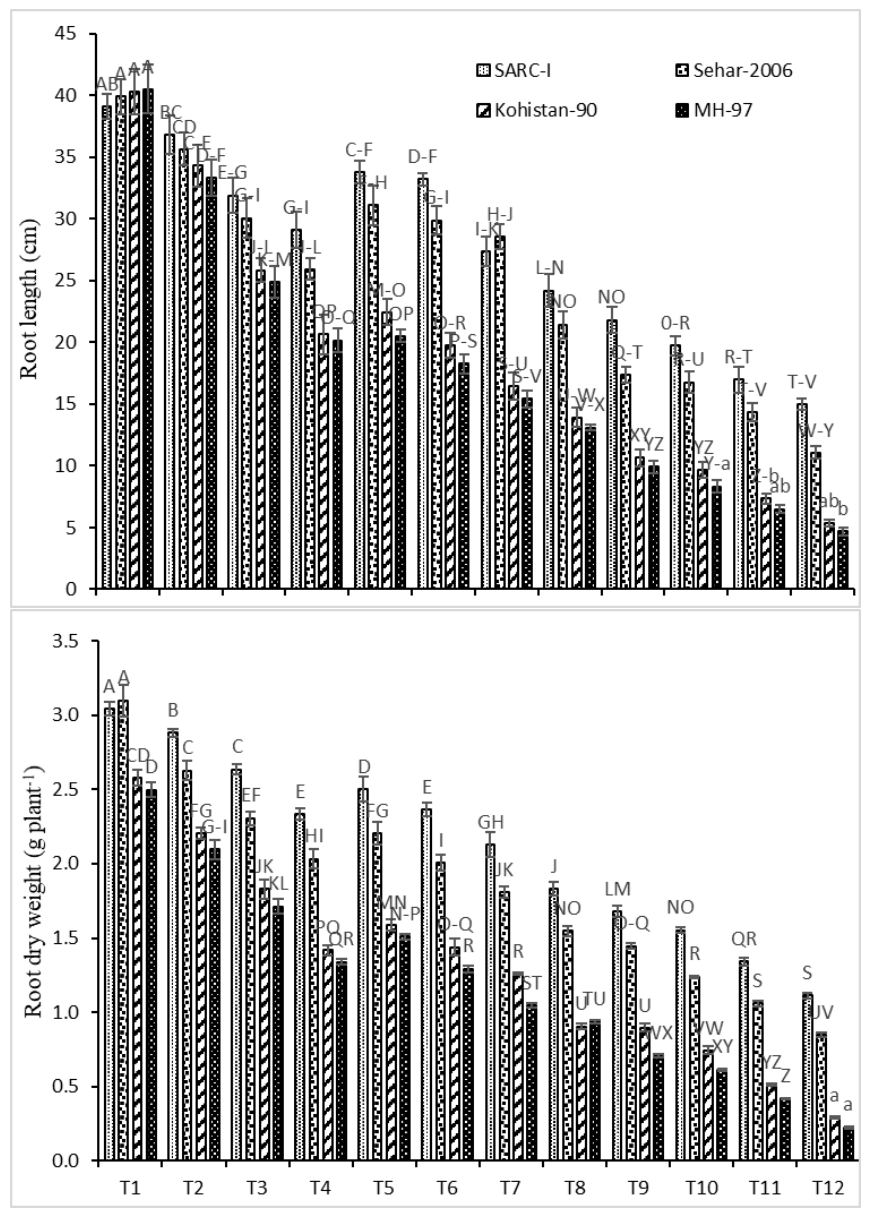

Figure 1b. Effect of varying levels of salinity and $B$ toxicity on growth responses of root (Means $\pm S E, n=4$ ). $\mathrm{T}_{1}=$ Control, $\mathrm{T}_{2}=0.5 \mathrm{mM} \mathrm{B}, \mathrm{T}_{3}=1 \mathrm{mM} \mathrm{B}, \mathrm{T}_{4}=1.5 \mathrm{mM}$ $\mathrm{B}, \mathrm{T}_{5}=100 \mathrm{mMNaCl}, \mathrm{T}_{6}=100 \mathrm{mMNaCl}+0.5 \mathrm{mM} \mathrm{B}$, $\mathrm{T}_{7}=100 \mathrm{mMNaCl}+1 \mathrm{mM} \mathrm{B}, \mathrm{T}_{8}=100 \mathrm{mMNaCl}+1.5$ $\mathrm{mM} \mathrm{B}, \mathrm{T}_{9}=200 \mathrm{mMNaCl}, \mathrm{T}_{10}=200 \mathrm{mMNaCl}+0.5 \mathrm{mM}$ $\mathrm{B}, \mathrm{T}_{11}=200 \mathrm{mMNaCl}+1 \mathrm{mM} \mathrm{B}, \mathrm{T}_{12}=200 \mathrm{mMNaCl}+$ $1.5 \mathrm{mM} \mathrm{B}$.

As the concentration of salinity and B increased in nutrition solution, the shoot and root growth decreased. The reduction in shoot and root growth by combined salinity and B treatments was higher than caused by either stress alone. However, the growth reduction was less than the sum of reduction caused by individual stresses when applied separately. In the current experiment, salinity was found as the dominant stress factor affecting plant growth. Among four genotypes used in present study, SARC-I was least affected by salinity, B and their interaction. The genotype Sehar-2006 also had statistically similar growth to SARC-I. While MH97 had minimum growth in response to applied salinity, B and their combined stresses (Fig. 1a, 1b).

In consonance with the present study results Masood et al. (2012) also reported that wheat growth was reduced by salinity, B and their combination. Holloway and Alston 
(Holloway and Alston, 1992) also found a decrease in wheat shoot and root growth by salinity, B and their interactive effects. These harmful effects on plant growth can be due to the reasons that salinity might lowered osmotic potential, caused ionic imbalance and specific ion toxicity (Ashraf and Harris, 2013) and B toxicity might have resulted in abnormal cell division in root meristem.

Grieve and Poss (2000) reported that shoot biomass of wheat seedlings was decreased to a greater extent by salinity than by B. It has been reported that root growth of plants subjected to B toxicity was reduced compared to plants grown at optimum B levels (Gunes et al., 2006). Cervilla et al. (2007) found that excess B supply resulted in inhibition of tomato root growth and tomato genotypes responded variably to high $\mathrm{B}$. The shoot dry weights of plants were affected adversely owing to increasing $\mathrm{B}, \mathrm{pH}$ and salinity-B interaction (Smith et al., 2013). The salts induced formation of ROS, alterations in nutrient uptake and turgor loss (Ashraf, 2009), hormonal imbalance and inhibition of cytoplasmic enzymes (Pitann et al., 2009) led to reduced cell division and elongation which impaired plant growth and yield.

Masood et al. (2012) also reported an additive effect of combined high B and salinity for reduction in wheat shoot growth. Wimmer et al. (2003) found higher reduction of root and shoot growth of wheat in response to combined B toxicity and salinity than their individual effects. The synergistic effects have also been reported (Alpaslan and Gunes, 2001). Similarly, antagonistic effect of combined salinity and B has been found in broccoli (Smith et al., 2010a) and wheat (Diaz and Grattan, 2009). Yermiyahu et al. (2008) reported an antagonistic impact of B toxicity and salinity on pepper growth and yield i.e., the damage produced by the two variables in combination was less than the sum of damage caused by them individually.

In present study, the wheat genotypes responded differently to interactive effects of B toxicity and salinity, and salt tolerant genotypes (i.e., SARC-I and Sehar-2006) showed better growth. Such tolerance of salinity and B can be due to inherent capacity of these genotypes and can contain more tolerant genes to confer stress (Din, 2008; Pallotta, et al., 2014). The other reason can be differential physiological and biochemical associations of tolerance mechanism and growth of plants (Fariduddin et al., 2012). Alpaslan and Gunes (2001) also reported that the salt tolerant tomato was affected less than salt sensitive cucumber plant and described that salt tolerant plants might have higher resistance to B toxicity as the salt exclusion mechanisms also reduced the uptake of B.

Physiological responses as affected by varying levels of salinity and B: Salinity, B and combined salinity and B treatments in growth medium significantly $(\mathrm{P} \leq 0.05)$ reduced PR, TR and SC in the tested wheat genotypes (Fig. 2). The genotypes showed substantial differences for physiological parameters; with Kohistan-90 and MH-97 having significantly higher reduction in PR, TR and SC than SARC-
I and Sehar-2006 (Fig. 2). Increasing salinity had more harmful effects on physiological parameters than $\mathrm{B}$ alone while combined salinity and B resulted in even higher reduction in PR, TR and SC. However, the decrease in the PR, TR and SC by combined salinity and B was less than the sum of decrease caused by salinity and B individually. The genotype SARC-I and Sehar-2006 maintained higher PR, TR and SC under increasing $\mathrm{B}$ as well as combined salinity and high B treatments than Kohistan-90 and MH-97.
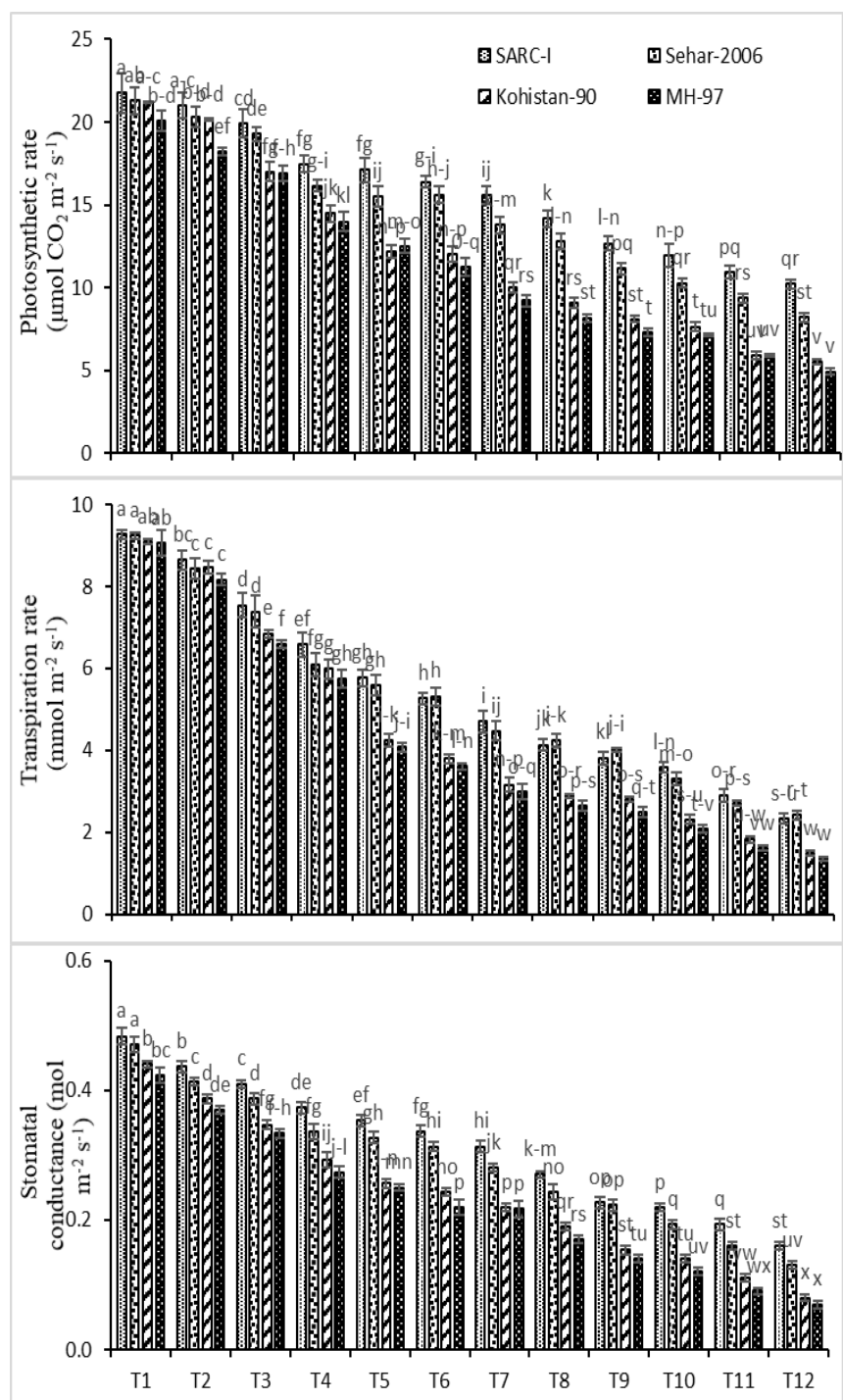

Figure 2. Effect of varying levels of salinity and B toxicity on wheat physiological responses (Means $\pm \mathrm{SE}, \mathrm{n}$ =4). $\mathrm{T}_{1}=$ Control, $\mathrm{T}_{2}=0.5 \mathrm{mM} \mathrm{B}, \mathrm{T}_{3}=1 \mathrm{mM} \mathrm{B}, \mathrm{T}_{4}=1.5$ $\mathrm{mM} \mathrm{B}, \mathrm{T}_{5}=100 \mathrm{mMNaCl}, \mathrm{T}_{6}=100 \mathrm{mMNaCl}+0.5 \mathrm{mM}$ $\mathrm{B}, \mathrm{T}_{7}=100 \mathrm{mMNaCl}+1 \mathrm{mM} \mathrm{B}, \mathrm{T}_{8}=100 \mathrm{mMNaCl}+$ $1.5 \mathrm{mM} \mathrm{B}, \mathrm{T}_{9}=200 \mathrm{mMNaCl}, \mathrm{T}_{10}=200 \mathrm{mMNaCl}+0.5$ $\mathrm{mM} \mathrm{B}, \mathrm{T}_{11}=200 \mathrm{mMNaCl}+1 \mathrm{mM} \mathrm{B}, \mathrm{T}_{12}=200$ $\mathrm{mMNaCl}+1.5 \mathrm{mM} \mathrm{B}$. 
Earlier reports also described that plants exposed to increasing salinity showed a reduced PR, accomplished by a significant decrease in SC and TR (Wani et al., 2013). According to Saleem et al. (2011) salinity induced abcisic acid accumulation causes stomata closure which limits the photosynthetic $\mathrm{CO}_{2}$ assimilation ultimately resulting in reduced photosynthetic capacity. Lu et al. (2009) stated that reduced PR under salt stress was related to the observed decrease in $\mathrm{SC}$ and substomatal $\mathrm{CO}_{2}$ concentration.

Excess of $\mathrm{B}$ in the growth medium inhibited the photosynthetic rate (Sheng et al., 2009). Boron toxicity resulted in reduced $\mathrm{CO}_{2}$ assimilation in citrus (Sheng et al., 2010). The reduced $\mathrm{CO}_{2}$ assimilation under $B$ toxicity can be due to several factors including decreased photosynthetic and enzymatic activities, impaired electron transport rate and oxidative load (Han et al., 2009). Pereira et al. (2000) described that thylakoids were structurally damaged due to B toxicity resulting in altered electron transport rate and ultimately decreased photosynthesis and $\mathrm{CO}_{2}$ photoassimilation. A reduction in SC was reported by Papadakis et al. (2004) in plants subjected to high B condition. Masood et al. (2012) reported a significant decrease in TR in wheat exposed to combined B toxicity and salinity.

Bastias et al. (2004) also reported the physiological effects of $\mathrm{B}$ and salt stress on Zea mays and observed that salt stress affected mainly water relations, growth and chlorophyll contents. They further explained that B absorption which is function of aquaporine functionality could vary according to plant sensitivity to salinity.

Ionic composition of plants as affected by varying levels of salinity and $B$ : There was a significant $(\mathrm{P} \leq 0.05)$ effect of treatments, genotypes and their combination for leaf $\mathrm{B}$ concentration (Fig. 3a). Concentration of B in the leaves of wheat genotypes increased significantly with increasing B under both non-saline and saline conditions (Fig. 3a). Higher leaf B concentration was found in Kohistan-90 and MH-97 compared to SARC-I and Sehar-2006 at high levels of B either alone or in combination with salinity. The leaf B concentration decreased with salinity than treatments having high B without salinity. The only exception was the lowest B level $(0.05 \mathrm{mM})$ where there was a constant increase with increasing salinity

Smith et al. (2010b) also reported that at low level of B, the increasing salinity increased shoot $\mathrm{B}$ concentration in broccoli; while at higher level of $\mathrm{B}$, the increased salinity decreased shoot B concentration. Masood et al. (2012) reported increase in apoplastic and symplastic soluble B concentrations with $\mathrm{NaCl}$ salinity at adequate $\mathrm{B}$ supply; while reduction in soluble $\mathrm{B}$ at high $\mathrm{B}$ level in the nutrient solution. Salinity reduced B uptake by plants but the impact was mainly evident at high substrate $\mathrm{B}$ concentrations, an observation also found in wheat by Wimmer and Goldbach (2012). Yermiyahu et al. (2008) determined that decreased leaf B concentration in the presence of salinity was due to reduced transpiration rates in plants. Smith et al. (2009) described that reduction in shoot B in broccoli due to salinity was more than what could be accounted for reduction in transpiration by salinity. They proposed that $\mathrm{B}$ uptake was not only the passive process and some exclusion mechanism was operative particularly at high substrate B concentration which resulted in reduced B uptake by plants.

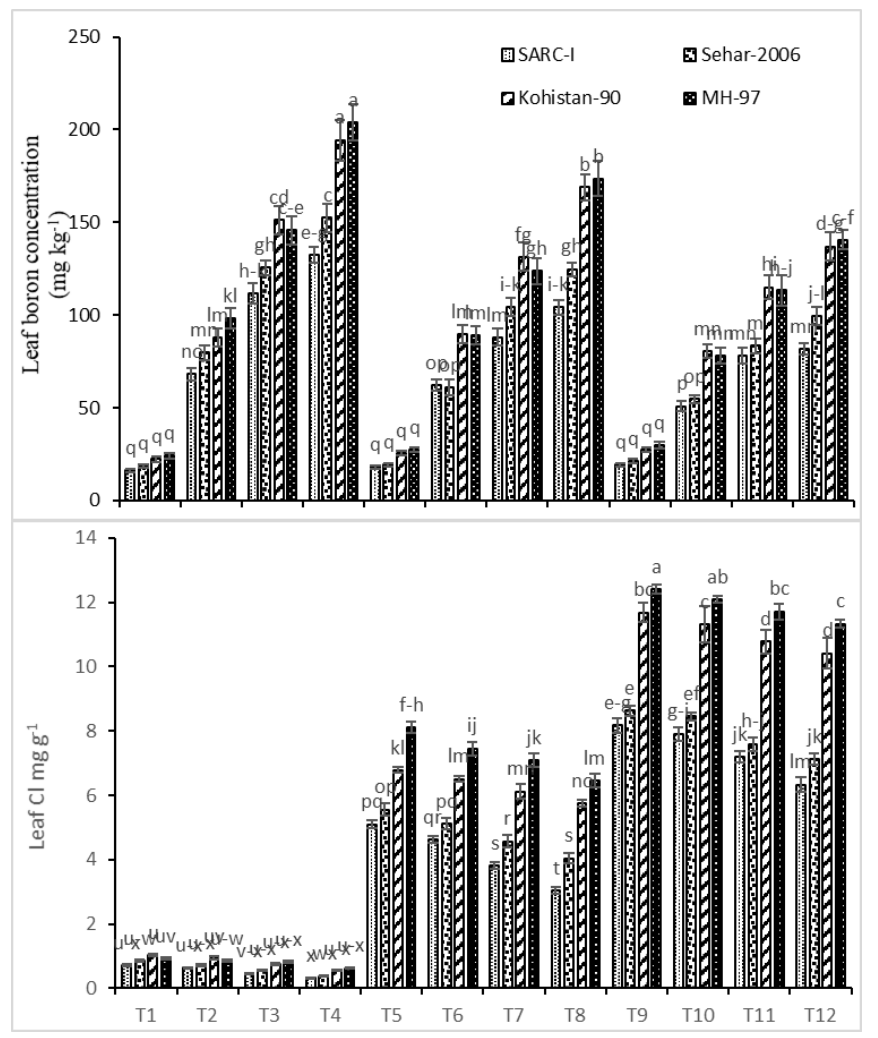

Figure 3a. Effect of varying levels of salinity and $B$ toxicity on wheat ionic $(\mathrm{B}, \mathrm{Cl})$ composition (Means $\pm \mathrm{SE}$, $\mathbf{n}=4) . T_{1}=$ Control, $T_{2}=0.5 \mathrm{mM} \mathrm{B}, \mathrm{T}_{3}=1 \mathrm{mM} \mathrm{B}, \mathrm{T}_{4}=$ $1.5 \mathrm{mM} \mathrm{B}, \mathrm{T}_{5}=100 \mathrm{mMNaCl}, \mathrm{T}_{6}=100 \mathrm{mMNaCl}+0.5$ $\mathrm{mM} \mathrm{B}, \mathrm{T}_{7}=100 \mathrm{mMNaCl}+1 \mathrm{mM} \mathrm{B}, \mathrm{T}_{8}=100 \mathrm{mMNaCl}$ $+1.5 \mathrm{mM} \mathrm{B}, \mathrm{T}_{9}=200 \mathrm{mMNaCl}, \mathrm{T}_{10}=200 \mathrm{mMNaCl}+$ $0.5 \mathrm{mM} \mathrm{B}, \mathrm{T}_{11}=200 \mathrm{mMNaCl}+1 \mathrm{mM} \mathrm{B}, \mathrm{T}_{12}=200$ $\mathrm{mMNaCl}+1.5 \mathrm{mM} \mathrm{B}$.

It was found by Reid and Fitzpatrick (2009) that B tolerant wheat genotypes relieved $\mathrm{B}$ toxicity in leaves and roots by means of B exporters expressed in both roots and leaves. At the plasma membrane, boric acid channels have been demonstrated to be involved in maintenance of low B concentrations inside the cells (Miwa and Fujiwara, 2010).

The concentration of $\mathrm{Cl}^{-}$was increased with increasing salinity in all wheat genotypes. However, increasing B either alone or in combination with salinity resulted in significant reduction of leaf $\mathrm{Cl}^{-}$concentration. Among wheat genotypes, MH-97 had the highest leaf $\mathrm{Cl}^{-}$concentration followed by Kohistan-90, Sehar-2006 and SARC-I (Fig. 3a). The 
increased concentration of $\mathrm{Cl}^{-}$is common response as a result of $\mathrm{NaCl}$ salinity (Wimmer et al., 2003). Similarly, Masood et al. (2012) found increase in $\mathrm{Cl}^{-}$concentration in wheat leaves with salinity. However, the leaf $\mathrm{Cl}^{-}$concentration decreased with B stress. Lee (2006) also reported reduced $\mathrm{Cl}^{-}$in hot pepper leaves in the presence of combined B toxicity and salinity than salinity alone. It is possible that B exporters also export the other anions such as $\mathrm{Cl}^{-}$along with $\mathrm{B}$ as a side effect and thus the concentration of $\mathrm{Cl}^{-}$is reduced in response to B toxicity.
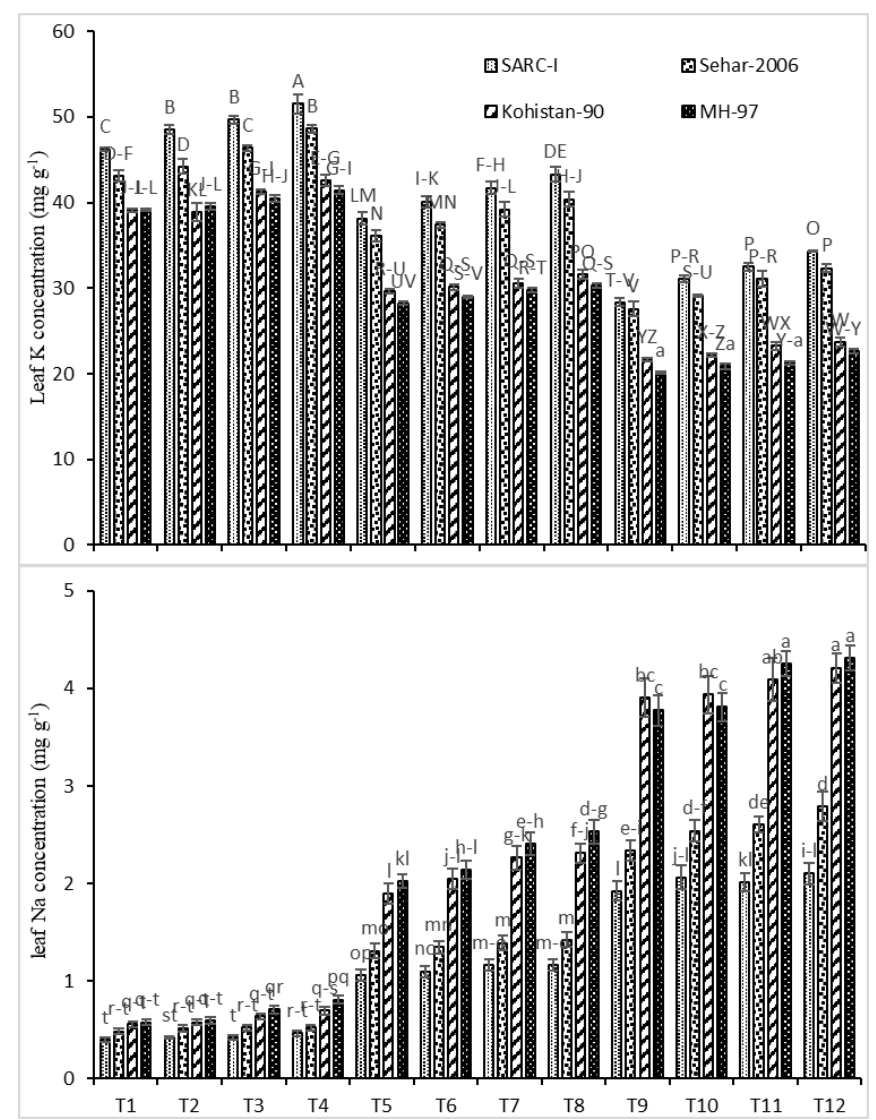

Figure 3b. Effect of varying levels of salinity and $B$ toxicity on wheat ionic $(\mathrm{K}, \mathrm{Na})$ composition (Means $\pm \mathrm{SE}$, $\mathbf{n}=4) . \mathrm{T}_{1}=$ Control, $\mathrm{T}_{2}=0.5 \mathrm{mM} \mathrm{B}, \mathrm{T}_{3}=1 \mathrm{mM} \mathrm{B}, \mathrm{T}_{4}=$ $1.5 \mathrm{mM} \mathrm{B}, \mathrm{T}_{5}=100 \mathrm{mMNaCl}, \mathrm{T}_{6}=100 \mathrm{mMNaCl}+0.5$ $\mathrm{mM} \mathrm{B}, \mathrm{T}_{7}=100 \mathrm{mMNaCl}+1 \mathrm{mM} \mathrm{B}, \mathrm{T}_{8}=100 \mathrm{mMNaCl}$ $+1.5 \mathrm{mM} \mathrm{B}, \mathrm{T}_{9}=200 \mathrm{mMNaCl}, \mathrm{T}_{10}=200 \mathrm{mMNaCl}+$ $0.5 \mathrm{mM} \mathrm{B}, \mathrm{T}_{11}=200 \mathrm{mMNaCl}+1 \mathrm{mM} \mathrm{B}, \mathrm{T}_{12}=200$ $\mathrm{mMNaCl}+1.5 \mathrm{mM} \mathrm{B}$.

With increasing salinity, the concentration of $\mathrm{Na}^{+}$in leaves increased in all genotypes. However, SARC-I and Sehar-2006 had significant lower leaf $\mathrm{Na}^{+}$concentration than Kohistan90 and $\mathrm{MH}-97$. The leaf $\mathrm{K}^{+}$concentration significantly decreased with increasing salinity in nutrient solution presumably due to the increased $\mathrm{Na}^{+}$concentration (Fig. 3b). In present study, no substantial difference for leaf $\mathrm{Na}^{+}$ concentration with increasing B level was found. However, leaf $\mathrm{K}^{+}$increased with increasing $\mathrm{B}$ levels in the growth medium. Among tested wheat genotypes, SARC-I and Sehar2006 had significant higher leaf $\mathrm{K}^{+}$than Kohistan-90 and $\mathrm{MH}-97$. A significant increase in $\mathrm{Na}^{+}$concentration in wheat shoot tissue was observed by Grieve and Poss (2000) exposed to increasing salinity in irrigation water. Substrate B also increased shoot $\mathrm{Na}^{+}$concentration and shoot $\mathrm{K}^{+}$was significantly decreased with salinity and further depressed by increasing substrate B. Smith et al. (2010b) observed reduced $\mathrm{K}^{+}$uptake in broccoli with increasing salinity and found that shoot $\mathrm{K}^{+}$was unaffected by changes in solution $\mathrm{B}$ concentration. In wheat leaves, the $\mathrm{Na}^{+}$concentration in leaves increased while the concentration of $\mathrm{K}^{+}$decreased with salinity (Wimmer al et. 2003). According to Blumwald et al. (2000) $\mathrm{Na}^{+}$induced $\mathrm{K}^{+}$deficiency and impaired $\mathrm{K}^{+} / \mathrm{Na}^{+}$ selectivity were the major factors for reduced growth and yield in saline conditions. This was caused by influx of $\mathrm{Na}^{+}$ through $\mathrm{K}^{+}$pathways.

Antioxidant enzymatic responses as affected by varying levels of salinity and $\boldsymbol{B}$ : The activity of antioxidant enzymes such as SOD and CAT was significantly $(\mathrm{P} \leq 0.05)$ affected by salinity, B, genotypes and their interaction (Fig. 4). The activity of both enzymes increased in response to increasing salinity and B with higher increase in response to salinity. Boron had lower effect on the activity of antioxidant enzymes than salinity. The enzyme activity was also increased in response to combined $\mathrm{B}$ toxicity and salinity. The SOD and CAT activities were higher in SARC-I and Sehar-2006 than Kohistan-90 and MH-97. This high activity of antioxidant enzymes was one of the important factors imparting higher tolerance in SARC-I in response to individual and combined B and salinity (Fig. 4).

Moghadam et al. (2014) also reported that CAT activity in wheat genotypes variably increased or decreased in response to salinity and the tolerant genotypes showed higher CAT activity. Sairam and Srivastava (2002) reported that the salt tolerant wheat genotype had higher CAT and SOD activity than the salt sensitive one. Barakat et al. (2013) found that salinity significantly increased CAT activity in pot grown wheat. Boron toxicity has also been reported to trigger the antioxidant enzymes activity (Papadakis et al., 2004; Kaya et al., 2009). Landi et al. (2013) reported significant increase in CAT and SOD in two cultivars of sweet basil in response to high concentration of $\mathrm{B}$ in nutrient solution. The activity of antioxidant enzymes in plants is not only affected by individual salinity or B toxicity but also by their combined presence. Lopez-Gomez et al. (2007) reported increased activity of SOD in the presence of combined B toxicity and salinity in Loquat plants indicating increased capability to scavenge superoxide radicals. In lettuce plants subjected to combined B toxicity and salinity, concentrations of SOD and CAT were increased (Eraslan et al., 2007). The tolerance of plants might be closely associated to enhanced capability of 
antioxidative systems to detoxify ROS and thereby reduce stress induced lipid peroxidation (Ardic et al., 2009). Under stress conditions, the enzymatic activities of the antioxidant system can be considered as an indicator of genotype tolerance to stress.
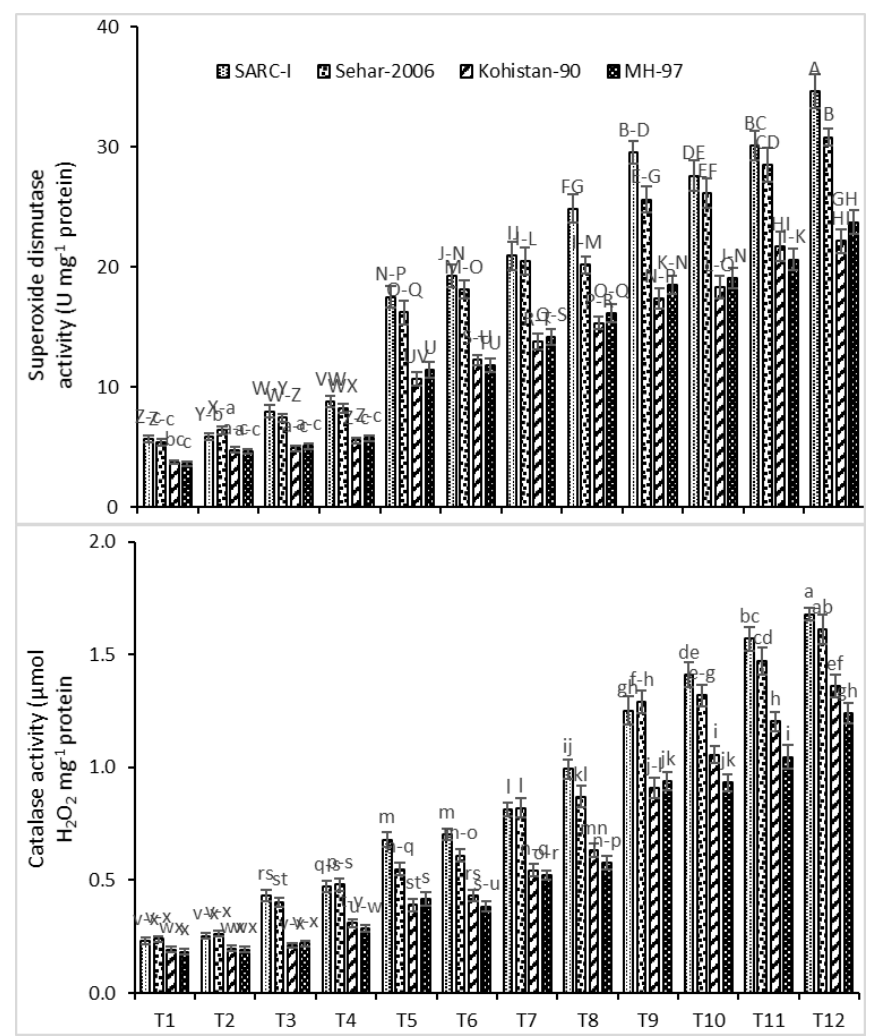

Figure 4. Effect of varying levels of salinity and B toxicity on wheat biochemical responses (Means $\pm \mathrm{SE}, \mathrm{n}$ =4). $\mathrm{T}_{1}=$ Control, $\mathrm{T}_{2}=0.5 \mathrm{mM} \mathrm{B}, \mathrm{T}_{3}=1 \mathrm{mM} \mathrm{B}, \mathrm{T}_{4}=1.5$ $\mathrm{mM} \mathrm{B}, \mathrm{T}_{5}=100 \mathrm{mMNaCl}, \mathrm{T}_{6}=100 \mathrm{mMNaCl}+0.5 \mathrm{mM}$ $\mathrm{B}, \mathrm{T}_{7}=100 \mathrm{mMNaCl}+1 \mathrm{mM} \mathrm{B}, \mathrm{T}_{8}=100 \mathrm{mMNaCl}+$ $1.5 \mathrm{mM} \mathrm{B}, \mathrm{T}_{9}=200 \mathrm{mMNaCl}, \mathrm{T}_{10}=200 \mathrm{mMNaCl}+0.5$ $\mathrm{mM} \mathrm{B}, \mathrm{T}_{11}=200 \mathrm{mMNaCl}+1 \mathrm{mM} \mathrm{B}, \mathrm{T}_{12}=200$ $\mathrm{mMNaCl}+1.5 \mathrm{mM} \mathrm{B}$.

Conclusion: The salinity and B toxicity individually and in combination significantly $(\mathrm{P} \leq 0.05)$ affected growth, physiological and biochemical responses of tested wheat genotypes. The both stress factors individually as well as in combination caused accumulation of toxic ions ( $\mathrm{Na}$ and $\mathrm{B}$ ) in wheat leaves, reduced PR, TR and SC in wheat genotypes, and induced oxidative stress and resultantly plant growth was affected. However the increasing boron levels under saline conditions mitigated the adverse effects of salinity on plant growth to some extent. Therefore, it can be concluded that in boron deficient salt affected soils, the application of boron fertilizers may be helpful for reducing harmful effects of salinity on plant growth. The stress tolerance of SARC-I and Sehar-2006 as indicated by better growth and physiological responses was due to the lower accumulation of toxic ions in leaves and higher activity of SOD and CAT.

\section{REFERENCES}

Agarwal, S. and V. Pandey. 2004. Antioxidant enzyme responses to $\mathrm{NaCl}$ stress in Cassia angustifolia. Biol. Plant. 48:555-560.

Alpaslan, M. and A. Gunes. 2001. Interactive effects of boron and salinity stress on the growth, membrane permeability and mineral composition of tomato and cucumber plants. Plant Soil. 236:123-128.

Ardic, M., A.H. Sekmen, S. Tokur, F. Ozdemir and I. Turkan. 2009. Antioxidant response of chickpea plants subjected to boron toxicity. Plant Biol. 11:328-338.

Ashraf, M. and P.J.C. Harris. 2013. Photosynthesis under stressful environments: An overview. Photosynthetica 51:163-190.

Ashraf, M. 2009. Biotechnological approach of improving plant salt tolerance using antioxidants as markers. Biotech. Adv. 27:84-93.

Barakat, N., V. Laudadio, E. Cazzato and V, Tufarelli. 2013. Antioxidant potential and oxidative stress markers in wheat (Triticum aestivum) treated with phytohormones under salt-stress condition. Int. J. Agric. Biol. 15:843849.

Bastias, E., N. Fernandez-Garcia and M. Carvajal. 2004. Aquaporin functionality in roots of Zea mays in relation to the interactive effects of boron and salinity. Plant Biol. 6:415-421.

Benderradji, L., S.B. Brini F,Amar, K. Kellou, J. Azaza, K. Masmoudi, H. Bouzerzour and M. Hanin. 2011. Sodium transport in the seedlings of two bread wheat (Triticum aestivum L.) genotypes showing contrasting salt stress tolerance. Aust. J. Crop Sci. 5:33-241.

Bingham, F.T. 1982. Boron. In: Page A.L. (ed.) Methods of Soil Analysis. Part 2: Chemical and Microbiological Properties. American Soc. of Agronomy, Madison, WI, USA. pp.431-448.

Blumwald, E., G.S. Aharon and M.P. Apse. 2000. Sodium transport in plant cells. Biochem. Biophy. Acta. 1465:140-151.

Cakmak, I., D. Strbac and H. Marschner. 1993. Activities of hydrogen peroxide-scavenging enzymes in germinated wheat seeds. J. Exp. Bot. 44:127-132.

Cervilla, L.M., B. Blasco, J.J. Rìos, L. Romero and J.M. Ruiz. 2007. Oxidative stress and antioxidants in tomato (Solanum lycopersicum) plants subjected to boron toxicity. Ann. Bot. 10:747-756.

Chance, B. and A.C. Maehly. 1995. Assay of catalase and peroxidases. Meth. Enzymol. 2:764-775.

Chapman, H.D. and P.F. Pratt. 1961. Method of analysis for soil, plants and waters. Uni. of California, Berkeley, CA, USA. 
Diaz, F.J. and S.R. Grattan. 2009. Performance of tall wheatgrass (Thinopyrum ponticum, cv. 'Jose') irrigated with saline-high boron drainage water: Implications on ruminant mineral nutrition. Agric. Ecosys. Environ.131:128-136.

Din, J., S.U. Khan and I. Ali. 2008. Physiological response of wheat (Triticum aesitivum L.) varieties as influenced by salinity stress. J. Anim. Plant Sci. 18:125-129.

Eraslan, F., A. Inal, O. Savasturk and A. Gunes. 2007. Changes in antioxidative system and membrane damage of lettuce in response to salinity and boron toxicity. Sci. Hort. 114:5-10.

Esfandiari, E., F. Shekari and M. Esfandiari. 2007. The effect of salt stress on antioxidant enzymes activity and lipid peroxidation on the wheat seedling. Not. Bot. Hort. Agrobot. Cluj. Napoca. 35:48-56.

Fariduddin, Q., B.A. Mir and A. Ahmad. 2012. Physiological and biochemical traits as tools to screen sensitive and resistant varieties of tomatoes exposed to salt stress. Braz. J. Plant Physiol. 24:281-292.

Faried, H.N., C.M. Ayyub, M. Amjad and R. Ahmed. 2016. Salinity impairs ionic, physiological and biochemical attributes in potato. Pak. J. Agri. Sci. 53:17-25.

Gong, H., X. Zhu, K. Chen, S. Wang and C. Zhang. 2005. Silicon alleviates oxidative damage of wheat plants in pots under drought. Plant Sci. 169:313-321.

Grieve, C.M. and J.A. Poss. 2000. Wheat response to interactive effects of boron and salinity. J. Plant Nutr. 23:1217-1226.

Guidi, L., E. Degl'Innocenti, G. Carmassi, D. Massaand and A. Pardossi. 2011. Effects of boron on leaf chlorophyll fluorescence of greenhouse tomato grown with saline water. Environ. Exp. Bot. 73:57-63.

Gunes, A., G. Soylemezoglu, A. Inal, E.G. Bagci, S. Coban and O. Sahin. 2006. Antioxidant and stomatal responses of grapevine (Vitis vinifera L.) to boron toxicity. Sci. Hort. 110:279-284.

Han, S., N. Tang, H.X. Jiang, L.T. Yang, Y. Lee and L.S. Chen. 2009. $\mathrm{CO}_{2}$ assimilation, photosystem II photochemistry, carbohydrate metabolism and antioxidant system of citrus leaves in response to boron stress. Plant Sci. 176:143-153.

Hernandez, J.A., M.A. Ferrer, A. Jimenez, A. Ros-Barcelo and F. Sevilla. 2001. Antioxidant systems and $\mathrm{O}_{2}{ }^{-} / \mathrm{H}_{2} \mathrm{O}_{2}$ production in the apoplast of Pisum sativum L. leaves: its relation with $\mathrm{NaCl}$-induced necrotic lesions in minor veins. Plant Physiol. 127:817-831.

Hoagland, D.R. and D.J. Arnon. 1950. The water culture method for growing plants without soil. California Agri. Exp. Station Circular 347:1-32.

Holloway, R.E. and M. Alston. 1992. The effects of salt and boron on growth of wheat. Aus. J. Agric. Res. 43:9871001 .
Ismail, A.M. 2003. Response of maize and sorghum to excess boron and salinity. Biol. Plant. 47:313-316.

Karabal, E., M. Yucel and H.A. Oktem. 2003. Antioxidant responses of tolerant and sensitive barley cultivars to boron toxicity. Plant Sci. 164:925-33.

Kaya, C., A.L.Tuna, M. Dikilitas, M. Ashraf and S. Koskeroglu. 2009. Supplementary phosphorus can alleviate boron toxicity in tomato. Sci. Hort. 121:284288.

Keles, Y., I. Oncel and N. Yenice. 2004. Relationship between boron content and antioxidant compounds in citrus leaves taken from fields with different water source. Plant Soil 265:345-353.

Landi, M., A. Pardossi, D. Remorini and L. Guidia. 2013. Antioxidant and photosynthetic response of a purpleleaved and a green-leaved cultivar of sweet basil (Ocimum basilicum) to boron excess. Environ. Exp. Bot. 85:64-75.

Lee, H.W. 2006. The relationship between boron content and crack properties in FCAW deposited Metal. Welding J. 85:131-136.

Lopez-Gomez, E., M.A. San-Juan, P. Diaz-Vivancos, J. Mataix-Beneyto, M.F. Garcia-Legaz and J.A. Hernandez. 2007. Effect of rootstocks grafting and boron on the antioxidant systems and salinity tolerance of loquat plants (Eriobotrya japonica Lindl). Environ. Exp. Bot. 60:151-158.

Lu, K.X., B.H. Cao, X.P. Feng, Y. He and D.A. Jiang. 2009. Photosynthetic response of salt tolerant and sensitive soybean varieties. Photosynthetica 47:381-387.

Masood, S., M.A. Wimmer, K. Witzel, C. Zorb and K.H. Muhling. 2012. Interactive effects of high boron and $\mathrm{NaCl}$ stresses on subcellular localization of chloride and boron in wheat leaves. Agron. Crop Sci. 198:227-235.

Miwa, K. and T. Fujiwara. 2010. Boron transport in plants: coordinated regulation of transporters. Annal. Bot. 105:1103-1108.

Moghadam, S.F., M. Ebrahimi, M.F. Najafabadi, H. Ramshini, S.A.S. Noori and S. Mansouri. 2014. The effect of salinity on antioxidant enzyme activity in bread wheat genotypes. $1^{\text {st }}$ Int. Conf. on New Ideas in Agriculture, Islamic Azad Uni. Khorasgan Branch. 26-27 January 2014, Isfahan, Iran.

Molassiotis, A., T. Sotiropoulos, G. Tanou, G. Diamantidis and L. Therios. 2006. Boron induced oxidative damage and antioxidant and nucleolytic responses in shoot tips culture of the apple rootstock EM9 (Malus domestica Borkh). Environ. Exp. Bot. 56:54-62.

Nable, R.O., G.S. Banuelos and J.G. Paull. 1997. Boron toxicity. Plant Soil 193:181-198.

Pallotta, M., T. Schnurbusch, J. Hayes A. Hay, U. Baumann, J. Paull, P. Langridge and T. Sutton. 2014. Molecular basis of adaptation to high soil boron in wheat landraces and elite cultivars. Nature 514:88-101. 
Papadakis, I., K.N. Dimassi, A.M. Bosabalidis, I.N. Therios and A. Patakas. 2004. Effects of B excess on some physiological and anatomical parameters of 'Navelina' orange plants grafted on two rootstocks. Environ. Exp. Bot. 51:247-257.

Parveen, M. Anwar-ul-Haq, J. Akhtar and S.M.A. Basra. 2016. Interactive effect of salinity and potassium on growth, biochemical parameters, protein and oil quality of soybean genotypes. Pak. J. Agri. Sci. 53:69-78.

Pereira, W.E., D.L. de-Siqueira, C.A. Martinez and M. Puiatti. 2000. Gas exchange and chlorophyll fluorescence in four citrus rootstocks under aluminium stress. J. Plant Physiol. 157:513-520.

Pitann, B., S. Schubert and K.H. Muhling. 2009. Decline in leaf growth under salt stress is due to an inhibition of $\mathrm{H}^{+}$ pumping activity and increase in apoplastic $\mathrm{pH}$ of maize leaves. J. Plant Nutr. Soil Sci. 172:535-543.

Reid, R and K.L. Fitzpatrick. 2009. Influence of leaf tolerance mechanism and rain on boron toxicity in barley and wheat. Plant Physiol. 151:413-420.

Sairam, R.K. and G.C. Srivastava. 2002. Changes in antioxidant activity in sub-cellular fractions of tolerant and susceptible wheat genotypes in response to long term salt stress. Plant Sci. 162:897-904.

Sairam, R.K., G.C. Srivastava, S. Agarwal and R.C. Meena. 2005. Differences in antioxidant activity in response to salinity stress in tolerant and susceptible wheat genotypes. Biolog. Plant 49:85-91.

Saleem, M., M. Ashraf and N.A. Akram. 2011. Salt ( $\mathrm{NaCl})$ induced modulation in some key physio-biochemical attributes in okra (Abelmoschus esculentus L). J. Agron. Crop Sci. 197:202-213.

Sheng, O., S.W. Song, S.A. Peng and X.X. Deng. 2009. The effects of low boron on growth, gas exchange, boron concentration and distribution of 'Newhall' navel orange (Citrus sinensisosb) plants grafted on two rootstocks. Sci. Hort. 121:278-283.

Sheng, O., G.F. Zhou, Q.J. Wei, S.A. Peng and X.X. Deng. 2010. Effects of excess boron on growth, gas exchange, and boron status of four orange scion-rootstock combinations. J. Plant Nutr. Soil Sci. 173:469-476.
Smith, T., S. Grattan, C. Grieve, J. Poss, A. Lauchli and D. Suarez. 2013. $\mathrm{pH}$ dependent salinity-boron interactions impact yield, biomass, evapotranspiration and boron uptake in broccoli (Brassica oleracea L.). Plant Soil. 370:541-554.

Smith, T.E., S.R. Grattan, C.M. Grieve, J.A. Poss and D.L. Suarez. 2010a. Salinity's influence on boron toxicity in broccoli: I. Impacts on yield, biomass distribution and water use. Agri. Water Manag. 97:777-782.

Smith, T.E., S.R. Grattan, C.M. Grieve, J.A. Poss and D.L. Suarez. 2010b. Salinity's influence on boron toxicity in broccoli: II. Impacts on boron uptake, uptake mechanisms and tissue ion relations. Agri. Water Manag. 97:783-791.

Steel, R.G.D., J.H. Torrie and D.A. Dickey. 1997. Principles and Procedures of Statistics: A Biometrical Approach, pp: 352-358, $3^{\text {rd }}$ Ed., McGraw Hill book Co. Inc., New York, USA.

US Salinity Lab Staff. 1954. Diagnosis and improvement of saline and alkali soils. United States Department of Agriculture, Handbook. No. 60. Washington, DC, USA.

Wani, A.S., A. Ahmad, S. Hayat and Q. Fariduddin. 2013. Salt-induced modulation in growth, photosynthesis and antioxidant system in two varieties of Brassica juncea. Saudi J. Biol. Sci. 20:183-193.

Wimmer, M.A. and H.E. Goldbach. 2012. Boron-and-salt interactions in wheat are affected by boron supply. J. Plant. Nutr. Soil Sci. 175:171-179.

Wimmer, M.A., K.H. Mühling, A. Läuchli, P.H. Brown and H.E. Goldbach. 2003.The interaction between salinity and boron toxicity affects the subcellular distribution of ions and proteins in wheat leaves. Plant Cell Environ. 26:1267-74.

Yamaguchi, T. and E. Blumwald. 2005. Developing salttolerant crop plants: challenges and opportunities. Trends Plant Sci. 10:615-620.

Yermiyahu, U., A. Ben-Gal, R. Keren and R.J. Reid. 2008. Combined effect of salinity and excess boron on plant growth and yield. Plant Soil. 304:73-87. 